\title{
Pathogenesis of cerebral malaria: new diagnostic tools, biomarkers, and therapeutic approaches
}

\author{
Praveen K. Sahu ${ }^{1}$, Sanghamitra Satpathi ${ }^{2}$, Prativa K. Behera ${ }^{2}$, Saroj K. Mishra ${ }^{1+}$, \\ Sanjib Mohanty ${ }^{1}$ and Samuel Crocodile Wassmer ${ }^{3,4 *}$
}

${ }^{1}$ Center for the Study of Complex Malaria in India, Ispat General Hospital, Rourkela, India, ${ }^{2}$ Department of Pathology, Ispat General Hospital, Rourkela, India, ${ }^{3}$ Department of Microbiology, New York University School of Medicine, New York, NY,

USA, ${ }^{4}$ Department of Pathology, The University of Sydney, Sydney, NSW, Australia

\section{OPEN ACCESS}

Edited by:

Nathan W. Schmidt,

University of Louisville, USA

Reviewed by:

Tracey Lamb,

Emory University School

of Medicine, USA

Jason Scott Stumhofer,

University of Arkansas for Medical

Sciences, USA

${ }^{*}$ Correspondence:

Samuel Crocodile Wassmer samuel.wassmer@nyumc.org

${ }^{\dagger}$ In memoriam

Received: 17 August 2015 Accepted: 05 October 2015 Published: 27 October 2015

Citation:

Sahu PK, Satpathi S, Behera PK,

Mishra SK, Mohanty S and

Wassmer SC (2015) Pathogenesis of

cerebral malaria: new diagnostic tools,

biomarkers, and therapeutic

approaches

Front. Cell. Infect. Microbiol. 5:75.

doi: 10.3389/fcimb.2015.00075
Cerebral malaria is a severe neuropathological complication of Plasmodium falciparum infection. It results in high mortality and post-recovery neuro-cognitive disorders in children, even after appropriate treatment with effective anti-parasitic drugs. While the complete landscape of the pathogenesis of cerebral malaria still remains to be elucidated, numerous innovative approaches have been developed in recent years in order to improve the early detection of this neurological syndrome and, subsequently, the clinical care of affected patients. In this review, we briefly summarize the current understanding of cerebral malaria pathogenesis, compile the array of new biomarkers and tools available for diagnosis and research, and describe the emerging therapeutic approaches to tackle this pathology effectively.

Keywords: cerebral malaria, Plasmodium falciparum, diagnostic, pathophysiology, research tools, new therapies

\section{CEREBRAL MALARIA: A COMPLEX AND MULTI-FACTORIAL SYNDROME}

Plasmodium falciparum malaria continues to be the predominant infectious disease in tropical and sub-tropical countries, with an estimated global incidence of 207 million cases and 627,000 deaths reported in 2012 (W.H.O., 2014). Cerebral malaria (CM) is a severe complication of P. falciparum infection. This complex and potentially reversible encephalopathy leads to coma and occurs with or without signs of compromise in other organs. There is no definite adjunctive therapy and even with highly effective antimalarial drugs and intensive care, mortality is 10-25\% (Taylor et al., 2004; Mishra and Newton, 2009). CM is most frequent in sub-Saharan Africa where the intense malaria transmission leads to widespread acquisition of immunity during childhood. Thus, CM is rare in adults and principally occurs in children under five (W.H.O., 2014). CM is also an important cause of mortality and morbidity in South East Asia, where malaria transmission is not sufficiently intense to induce robust immunity. In this region, CM principally occurs in older children and adults.

There are significant differences in the pattern of vital organ dysfunction in CM between African children and South East Asian adults (Trang et al., 1992; Marsh et al., 1995; Newton et al., 1998; Wassmer et al., 2015) for which the mechanism is poorly understood. In adults, central nervous system dysfunction frequently occurs in conjunction with failure of other organ systems, particularly renal and respiratory. In contrast, African children have a more purely neurological disease, with rapid onset of coma, anemia and seizures, but overt respiratory or renal compromise is generally absent (Newton et al., 1998; Miller et al., 2013). Neuropathological dissimilarities were 
also described: African children present prominent accretions of fibrin (Dorovini-Zis et al., 2011; Moxon et al., 2013; Milner et al., 2014), platelets (Grau et al., 2003), and inflammatory infiltrates within the neurovasculature. These features are less marked or absent in Southeast Asian adults (Macpherson et al., 1985; Turner et al., 1994; Hawkes et al., 2013).

Several processes have been implicated in CM pathogenesis, including microvascular obstruction by $P$. falciparum-parasitized red blood cell (PRBC; Berendt et al., 1994), excessive proinflammatory cytokine production (Clark and Rockett, 1994), microvascular thrombosis (van der Heyde et al., 2006; Moxon et al., 2009), loss of endothelial barrier function (Beare et al., 2009; Dorovini-Zis et al., 2011), and endothelial dysregulation (Wassmer et al., 2011). The way these pathological mechanisms are linked and how they are influenced by host and parasite factors remains to be elucidated. In addition, the reasons why circulating cytokines, coagulation factors, or PRBC specifically target only the brain in African children, and the brain as well as other organs in Southeast Asian adults, are still unclear.

In order to better understand the factors leading to the development of $\mathrm{CM}$ and subsequently improve the outcome for affected patients, a new range of techniques and sets of biomarkers for severity have recently been developed. The present review focuses on these innovative advances, which offer a new panel of tools for malaria researchers and clinicians in the field.

\section{NOVEL INVESTIGATIVE TECHNIQUES}

\section{Clinical Neuroimaging}

Advanced imaging devices have become increasingly accessible to malaria-endemic countries in recent years, allowing a leap forward in terms of clinical studies aimed at elucidating the etiology of CM.

\section{Magnetic Resonance Imaging}

MRI yields very useful clinical information and provides a measure of several neurological parameters impossible to assess otherwise, e.g., nature of cerebral blood flow alteration and damage to neural tissue. The study by Penet et al. (2005) was the first to perform MRI of the murine model of CM, and demonstrated vascular damage attributable to inflammatory processes. Subsequently, MRI techniques also allowed the analysis of neuronal axon injury during CM (Kennan et al., 2005), as well as the investigation of the diffused cerebral swelling of brainstem in 120 Malawian children with CM (Potchen et al., 2012). By allowing the comparison of specific parameters between $\mathrm{CM}$ patients who survive and those who succumb to the disease, the use of MRI has been instrumental in highlighting an increased intracranial pressure and brain stem herniation in fatal cases (Seydel et al., 2015). This study not only suggested for the first time a cause of death in pediatric CM, but also new potential therapeutic approaches aimed at decreasing the intracranial pressure in affected patients.

\section{Computed Tomography}

Unlike MRI, CT scans are now commonly available in malariaendemic countries. Their pioneering use in $\mathrm{CM}$ patients from Thailand and Kenya suggested for the first time the involvement of cerebral edema in the development of the pathology (Looareesuwan et al., 1983; Newton et al., 1994). Subsequently, a study in India showed that CT findings correlate well with level of consciousness and severity of disease but do not reveal the extent of the pathology permitted by postmortem examinations (Patankar et al., 2002). CT imaging is particularly helpful for the determination of cerebral volume variation and the detection of infarctions in large vessels, as recently demonstrated in a pediatric $\mathrm{CM}$ patient population (Potchen et al., 2010). In children with retinopathy-confirmed CM, acute head CTs revealed findings consistent with autopsy studies and showed abnormality in basal ganglia, white matter and corpus callosum. Follow-up images in survivors allowed the identification of lesions consistent with acute symptomatology and chronic deficits. CT imaging was used in a consequent study to evaluate and map brain swelling in Indian adults with CM and assess the potential benefits of mannitol as an adjunct therapeutic agent (Mohanty et al., 2011). The study was the largest of its kind, including 126 Asian adult patients with CM. Their systematic acute head CT scans revealed that $29 \%$ had moderate to severe brain swelling. There was, however, no significant correlation between swelling and coma depth and mortality in the series.

\section{Investigative Neuro-imaging Tools}

While the use of neuroimaging techniques has contributed to a better understanding of the pathophysiology of CM, novel and revolutionary approaches have become available in the laboratory but are not applicable directly to patients. For this, the experimental model, albeit limited (Craig et al., 2012), represents a useful tool to investigate the pathogenesis of CM at the cellular and molecular level in the brain.

\section{In vivo Bioluminescent Imaging}

In vivo bioluminescent imaging is a versatile and sensitive tool that is based on the detection of light emission from cells or tissues. The technique has been allowed by the genetic modification of malaria parasites and the production of luciferase-expressing lines. This, coupled with the development of imaging systems to detect cells expressing reporter genes, has significantly broadened the possibilities for in vivo studies of interactions between Plasmodium spp. parasites and their hosts (Franke-Fayard et al., 2006). Optical imaging by bioluminescence allows a low-cost, non-invasive and real-time analysis of disease processes at the molecular level in experimental animals. It also permits longitudinal monitoring of the course of the pathology in the same animal, and the imaging of transgenic fluorescent or bioluminescent malaria parasites is now widely used as a tool to assess parasite distribution during experimental CM. A recent study used real-time in vivo imaging to evaluate the contribution of different immune mediators to PRBC accumulation and distribution during the development of experimental CM. The results showed that $\mathrm{CD} 8+\mathrm{T}$ cells and IFN- $\gamma$ are responsible for the rapid increase in total parasite biomass, as well as for the accumulation of PRBC in the brain and in different organs (Claser et al., 2011). These in vivo pathogenesis studies can also be carried out with a different bioluminescent target, as shown by Imai and colleagues, who evaluated oxidative stress during 
experimental CM using OKD48 (Keap1-dependent Oxidative stress Detector, No-48-luciferase) mice. Oxidative stress in the brain can be visualized in these animals after injection of luciferin, and an elevated bioluminescent signal was associated with the development of the pathology (Imai et al., 2014). Lastly, this imaging technique can also used for the assessment of parasite virulence (Spaccapelo et al., 2010) and provides a simple and reliable framework for in vivo antimalarial and CM adjunctive treatment screening by monitoring post-treatment changes in bioluminescence signal, which correlates with the degree of parasitemia in the animal (Franke-Fayard et al., 2008).

\section{Intra-vital Microscopy}

Recently developed, this advanced imaging tool allows the direct and live visualization of the brain via a cranial opening (Volz, 2013). The technique can reveal cellular responses over time and space during the course of experimental CM and can be conducted under conditions closely approximating those of a natural environment. In addition, it presents the advantage of observing in vivo pathological events in the brain, including variations in hemodynamic events (Nacer et al., 2014) and vascular leakages (Frevert et al., 2014). By comparing the variation of these parameters between control and treated animal groups, intra-vital microscopy has allowed the assessment of intervention drugs, including nimodipine and nitric oxide (NO) therapy (Cabrales et al., 2011; Zanini et al., 2011; Rénia et al., 2012). It is a versatile platform, as demonstrated by two recent and innovative studies. First, Cabrales and colleagues performed the direct, quantitative, and dynamic analysis of fluctuations of oxygen transport and tension during experimental $\mathrm{CM}$ progression and its contribution to the severity of disease. Results highlighted the pial tissue as highly sensitive to changes in blood flow, anemia, and low oxygen tension impacting sufficient oxygen delivery (Cabrales et al., 2013). Second, Pai and colleagues used of a novel, two photon-based approach, which allowed them to monitor the behavior of leukocytes in cerebral microvessels during the development of the pathology in infected mice. A decrease in the rolling velocity of monocytes, a measure of endothelial cell activation, was associated with the progressive worsening of signs in the animals. These modifications were mediated by Plasmodium-specific CD8+ T lymphocytes, suggesting their direct influence in the regulation of vascular pathology associated with the development of experimental CM (Pai et al., 2014).

\section{${ }^{18}$ F-Fluorodeoxyglucose (FDG) Positron Emission Tomography (PET)}

FDG-PET is a non-invasive imaging tool used to map cerebral metabolic activity by quantifying the uptake of a glucose analog by brain cells. This metabolic activity was measured in vivo during the progression of experimental CM in the Plasmodium coatneyi primate model of the pathology (in which there is significant cerebral sequestration). The analysis revealed diffuse and heterogeneous reduction of metabolism in the cortex during the acute phase of infection (Sugiyama et al., 2004). These results are consistent with a focal impairment of the microcirculation, potentially induced by PRBC sequestration. However, it is plausible that this reduced metabolic activity safeguards the cerebral tissue against hypoperfusion, as an inherent function of the microcirculatory system is to protect organs from the effects of diminished oxygen and metabolite supply (Ellis et al., 2005). This could explain why more than half of CM patients present no neurological sequelae following recovery (Kawai and Sugiyama, 2010). Another study showed reduced cerebral blood flow during CM using an FDG-PET in a murine model of experimental CM (Kennan et al., 2005). FDG-PET was recently used systematically in a cohort of patients to help the diagnosis of fever of unknown origin (Tokmak et al., 2014), showing that this approach might become available to CM patients soon and may be able to complement the ongoing MRI studies to shed some light on the pathophysiological processes during the neurological syndrome.

\section{NEW DIAGNOSTIC TOOLS}

In addition to prevention strategies and effective treatment, one of the most important factors influencing the outcome of CM is its early diagnosis. According to a study published in 2004, about a quarter of the pediatric patients diagnosed with CM using the WHO criteria were shown at autopsy to have died of non-CM causes (Taylor et al., 2004), which highlights the importance of accurate and reliable diagnostic tools.

\section{Malarial Retinopathy}

The sequestration of $P$. falciparum-infected red blood cells (PRBC) in the cerebral microvasculature is the hallmark of CM. In pediatric patients, retinal microvessels have been shown to sustain damage comparable to the ones occurring in the brain, making them an easily observable surrogate marker to assess the severity of cerebral pathology during CM (Beare et al., 2006; Maude et al., 2009). In recent years, the approaches adopted to assess and document the retinal changes during CM have evolved rapidly and are now available for clinical studies in endemic areas.

\section{Funduscopy}

Funduscopy is a relatively low-cost and easy technique to assess the presence of retinopathies, which allows the accurate distinction between malaria and non-malaria coma in CM patients. Retinal changes include vessel color changes, whitecentered hemorrhages, and peri- and extramacular whitening. The severity of these changes during $P$. falciparum infection correlates strongly with patient mortality, and the identification of markers associated with the presence of retinopathies and therefore, of CM, may allow the early detection of patients at risk (Kariuki et al., 2014; Maccormick et al., 2014).

\section{Optical Coherence Tomography (OCT)}

OCT is an in vivo imaging tool for the detection of retinal changes. This imaging technique allows optical-signal acquisition by which high-resolution cross-sectional images of the retina, optic nerve-head and even the thickness of the retinal nerve 
fiber layer can be acquired and both qualitative and quantitative evaluations can be made (Sakata et al., 2009). Despite its non-invasive nature and high-resolution output, the use of OCT in malarial retinopathy has been difficult to implement systematically so far due to its costs, as well as practical issues. Indeed, patients need to be seated upright for the retinal analysis, which is problematic for comatose CM patients in intensive care units. However, a case of $P$. vivax retinopathy has been recently described using OCT (Lee et al., 2010), showing that the new development in high-resolution and high-speed OCT, along with the improvement in portability (Huang and Hirose, 2012) might make the technology extremely valuable for retinopathy analyses in malaria-endemic areas.

\section{Teleophthalmology}

While the use of retinopathy has helped increasing the accuracy of diagnosis in African children and more recently in Asian adults (Sayeed et al., 2011), its use is still infrequent, as systematic funduscopy requires a trained ophthalmologist, as well as expensive equipment that is not always available in field clinics. This has led to the recent development of easy-to-handle and affordable retinal cameras (Maude et al., 2011), as well as the emergence of modified handheld portable devices such as smartphones. In addition to their telecommunication functions, the most recent models possess diagnostic-quality imaging facility that meet the criteria necessary for accurate fundus examination and rapid diagnosis of retinopathy (Kumar et al., 2012; Maamari et al., 2014). This revolutionary "teleophthalmology" can be performed using cheap 3D printed fittings where the built-in flash of the phone provides the light source, and an installed application allows the easy and rapid photo-documentation of retinal abnormalities in CM patients (Myung et al., 2014). Such devices can be operated by healthcare workers after minimal training and the saved images can be sent by SMS or email to an ophthalmologist for rapid diagnosis.

\section{Fluorescein Angiogram Framework}

In order to help accurtely establish the presence of retinopathy in $\mathrm{CM}$, the automated analysis of the retinal vasculature has become an active research area in the field of medical imaging in the recent years, both for its diagnostic and prognostic significance (Beare et al., 2004). A prerequisite to this appoach is the automated detection of blood vessels, and the past decade has witnessed the rapid development of methods for retinal vessel segmentation (Fraz et al., 2012). A recent study has demonstrated the novel use of an automated segmentation approach in fluorescein angiography, to extract retina vessel images and build an analysis framework (Zhao et al., 2015). The latter includes four main components: vessel segmentation, analysis of vessel geometry, salient feature generation, and vessel classification. This automated analysis to classify retinal vessel abnormalities showed an overall sensitivity, specificity, and accuracy similar to the ones obtained using two direct observers. Coupling this new approach to the teleophthalmology described above would allow a direct diagnosis of CM without sending acquired pictures of the retina to an off-site ophthalmologist, leading to a faster treatment of the patient.

\section{Electroencephalography (EEG) and Micro-EEG EEG}

This non-invasive technique to record electrical impulses of the brain by measuring voltage fluctuations due to ionic current within the neural tissue has been used in CM patients since the early 1990s (Thumasupapong et al., 1995). Prolonged and multiple seizures complicate a high proportion of cases of $\mathrm{CM}$ and can damage brain tissue by aggravating hypoxia, hypoglycemia, and intracranial hypertension. In recent years, the use of EEG has allowed the detection of these delayed CM sequelae, including neurodisabilities such as status epilepticus. Acute and serial EEGs are especially important for identifying subclinical seizures. A study performed in Kenya revealed that in about $25 \%$ of the enrolled pediatric CM patients, coma is due to continuing subtle seizure activity which is likely to go undetected, but is responsive to anticonvulsant drugs (Crawley et al., 1996). Subsequent studies in Kenya and in Mali showed an increased prevalence of epilepsy in patients who survived CM (Carter et al., 2004; Ngoungou et al., 2006). The recent inclusion of retinopathy as a criteria for CM diagnostic in a study in Malawian children helped to improve the accuracy of the diagnosis in enrolled patients, and to identify children with pre-existing neurological injuries, predispositions to adverse neurological outcomes, or non-malarial causes of coma. In this carefully defined cohort, almost a third of retinopathy-positive CM survivors developed epilepsy or other neurobehavioral sequelae (Birbeck et al., 2010).

\section{Micro-EEG}

One major limitation of the EEG studies is the serial postdischarge follow-up assessments, which involve multiple patient visits to the hospital, or home-based visits by nurses. These are not always possible and often present a logistical hindrance to EEG studies in the field. However, a miniature version of the EEG equipment is now available as a portable headgear that can accommodate up to 32 electrodes and connects via Bluetooth technology to a small monitoring machine. The micro-EEG diagnostic accuracy of status epilepticus is comparable to that of standard EEG systems (Grant et al., 2014) and will greatly facilitate not only the recording of brain as an easy diagnostic tool (Omurtag and Fenton, 2012), but will also allow an easier continuous recording of the patient after discharge. Indeed, patients can leave the hospital with the device and come back once the recording period is over. The tools is expected to soon be used for rapid monitoring and imaging of neuropathological sequelae, as well as a standard routine assessment in comatose patients with CM, as is already initiated in a phase 1 and 2 clinical trial for levetiracetam, a medication to control the seizures associated with pediatric CM (http://www.clinicaltrials.gov/ct2/ show/study/NCT01660672).

\section{BIOMARKERS}

Biomarkers include tools and technologies that can facilitate the prediction, cause, diagnosis, progression, regression, or outcome of treatment of disease. For pathologies of the nervous system, there is a wide range of techniques used to gain information 
about the brain in both the healthy and diseased state. These involve measurements directly on biological media such as blood or cerebrospinal fluid (CSF) from the patients; or measurements via brain imaging, which do not involve direct sampling of tissue but measure changes in the composition or function of the nervous system. While biomarkers have been used to diagnose and prognosticate the progress and outcome of many chronic diseases, the field of malaria research only recently moved in the direction of actively identifying biomarkers that can accurately discriminate the severe forms of malaria, and in particular, CM. Such biomarkers, once identified, validated, and integrated into rapid diagnostic tests, could allow the accurate and early identification of CM patients and their subsequent referral to tertiary healthcare facilities for prompt intervention. Recent clinical studies have identified serological factors that have the potential of being biomarkers. Based on their function and stage(s) of usage, these can be classified as early screening and diagnosis biomarkers, as well as prognostic biomarkers (Table 1).

\section{Early Screening and Diagnosis Biomarkers}

Biomarkers used for early screening or diagnosis are used as an indicator of a biological factor that represents either a subclinical manifestation, stage of the disorder, or a surrogate manifestation of the disease. Early screening biomarkers allow the identification of individuals destined to become affected or who are in the "preclinical" stages of the illness. Unfortunately, due to the rapid development of CM and the late presentation of the patients to hospitals, longitudinal analyses of plasma from patients with falciparum malaria have not been feasible so far and potential early screening biomarkers for CM before the onset of symptoms are yet to be identified. However, serological factors that allow the accurate discrimination of CM after the onset of symptoms have been described in the recent years. These biomarkers are indicative of pathology, as they are based on specific processes that have been associated with the development of CM (Figure 1). For instance, the role of endothelial intra-cellular adhesion molecule-1 (ICAM-1) in the sequestration of PRBC is well-understood, and specific binding of PRBC to ICAM-1 has been implicated in the development of CM (Smith et al., 2000). High levels of plasma soluble ICAM-1 were found to be associated with the development of CM in Ghanaian children, and these levels may reflect the upregulation of ICAM-1 in the cerebral microvasculature (Adukpo et al., 2013). Angiopoetin-1 and -2 (ANG-1 and -2) are critical regulators of endothelial activation and integrity, and their levels have also been described as reliable biomarkers of CM. Indeed, ANG-1 and -2 levels profiled from serum or whole blood were shown to discriminate accurately between cerebral and uncomplicated malaria in African patients (Lovegrove et al., 2009), and between cerebral, severe non-cerebral malaria, and uncomplicated malaria in a cohort of Thai patients (Conroy et al., 2009). Compared to UM, CM patients presented significant decreases in ANG-1 and increases in ANG-2 levels and the ratio of ANG-2:ANG-1. This is consistent with the pathophysiology of CM, which involves endothelial activation and dysfunction. Indeed, ANG-1 maintains vascular quiescence, while ANG-2 displaces ANG-1 upon endothelial activation and sensitizes the cells to become responsive to sub-threshold concentrations of tumor necrosis factor (TNF; Kim et al., 2011). Estimation of Plasmodium falciparum histidine rich protein 2 (PfHRP2) in the plasma samples has also been shown to be an accurate diagnostic tool to ascertain the parasite biomass in severe malaria patients, and allowed the distinction between severe and uncomplicated malaria (Hendriksen et al., 2012; Imwong et al., 2015). Clinical studies have also shown that PfHRP2 can be present in the CSF of patients with CM (Mikita et al., 2014). More recently, the use of advanced affinity-proteomic tools employing a high-throughput platform of specific antibodies for candidate screening has allowed a wider analysis of potential diagnosis biomarkers for the neuropathology. The plasma levels of 1015 muscle proteins were measured in 700 children and Bachmann and colleagues showed that high levels of four specific smooth muscle proteins exhibit high correlation with the development of endothelial injury and microvasculature lesions during $\mathrm{CM}$, including the smooth muscle cells that surround the endothelial cell monolayer in the tunica media of post-capillary venules (Bachmann et al., 2014). This is in concordance with the presence of vascular and microvascular lesions complicated by ring hemorrhages in comatose $\mathrm{CM}$ patients (Ponsford et al., 2012). In addition, as ANG-1 is primarily produced by vascular smooth muscle cells (van Meurs et al., 2009), their injury could result in a reduced production of the angiogenic factor, leading to its low levels during CM. Further studies are warranted but these proteins could represent new biomarkers for the severity of CM and allow prompt therapeutic measures.

\section{Prognostic Biomarkers}

Prognostic biomarkers provide information on the likely course of the disease in an individual. Plasma levels of ANG-1 and ANG-2 can also predict the clinical outcome of CM, according to studies performed in African children (Lovegrove et al., 2009) and in Indian adults (Jain et al., 2011), in which low ANG-1 levels on presentation was associated with a fatal outcome. This may indicate that, in addition to antiparasitic drugs, ANG-1 is needed to reverse the deleterious endothelial activation in $\mathrm{CM}$ and prevent death (Wassmer et al., 2015). CXCL10 and CXCL4 (C-X-C motif chemokine 10 and 4), the ligands of chemokine receptor CXCR3, were described as another set of prognostic biomarkers in CM (Wilson et al., 2011). Indeed, high plasma levels of the chemokines were found to be significantly associated with mortality in CM patients. CXCL10 is produced by a variety of cells, including endothelial cells. The effects of elevated levels of CXCL10 on the cerebral microvasculature are unknown but are suspected to cause local injuries by recruiting mononuclear leukocytes, inducing focal hyperinflammation (Jain et al., 2008). In addition, CXCL4 is released from activated platelets and stimulates TNF production by mononuclear leukocytes, a key proinflammatory cytokine associated with the development of CM. This study established that CXCL10 and CXCL4 can be routinely used to predict the mortality risk in $\mathrm{CM}$ patients in endemic settings. Along with the clinical diagnosis of CM, the presence of PfHRP2 in CSF can also be used to predict 
TABLE 1 | Pathogenesis of cerebral malaria: recent discoveries and potential biomarkers.

\begin{tabular}{|c|c|c|c|c|c|}
\hline Biomarker & Abbreviations & Type/Site & Method & Indicative events & Study \\
\hline \multicolumn{6}{|c|}{ HUMAN CEREBRAL MALARIA } \\
\hline $\begin{array}{l}\text { von Willebrand factor } \\
\text { (WWF), propeptide }\end{array}$ & $\begin{array}{l}\text { WWF, WWF } \\
\text { propeptide }\end{array}$ & Plasma & ELISA based assays & $\begin{array}{l}\text { Indicates acute and excessive endothelial } \\
\text { cell activation (Weibel-Palade exocytosis) }\end{array}$ & $\begin{array}{l}\text { Hollestelle et al., 2006; } \\
\text { Bridges et al., } 2010\end{array}$ \\
\hline Erythropoietin & Epo & CSF & ELISA based assays & $\begin{array}{l}\text { High levels are associated with a } \\
\text { neuroprotective role in pediatric CM }\end{array}$ & $\begin{array}{l}\text { Casals-Pascual et al., } \\
2008\end{array}$ \\
\hline \multirow[t]{3}{*}{ Angiopoetin-1, -2 } & ANG-1, ANG-2 & $\begin{array}{l}\text { Endothelial (whole } \\
\text { blood levels) }\end{array}$ & ELISA based assays & $\begin{array}{l}\text { ANG-1 and - } 2 \text { levels from whole blood } \\
\text { allow the accurate discrimination between } \\
\text { cerebral, severe (non-cerebral) malaria and } \\
\text { uncomplicated malaria }\end{array}$ & Conroy et al., 2009 \\
\hline & & $\begin{array}{l}\text { Endothelial (serum } \\
\text { levels) }\end{array}$ & ELISA based assays & $\begin{array}{l}\text { Low ANG-1 levels at presentation is } \\
\text { indicative of a poor outcome; Serum } \\
\text { ANG-1 levels are significantly decreased } \\
\text { and ANG-2 levels increased in children } \\
\text { with CM compared to uncomplicated } \\
\text { malaria patients and healthy controls }\end{array}$ & Lovegrove et al., 2009 \\
\hline & & $\begin{array}{l}\text { Endothelial (plasma } \\
\text { levels) }\end{array}$ & ELISA based assays & $\begin{array}{l}\text { Low ANG-1 levels at admission and } \\
\text { gradual increase with recovery are } \\
\text { observed, suggesting ANG-1 as a } \\
\text { potential marker of clinical response in CM } \\
\text { patients }\end{array}$ & Conroy et al., 2010 \\
\hline $\begin{array}{l}\text { Ligands of chemokine } \\
\text { receptor CXCR3 }\end{array}$ & CXCL4, CXCL10 & CSF, serum & ELISA based assays & $\begin{array}{l}\text { Enhanced plasma levels of CXCL10 and } \\
\text { CXCL } 4 \text { are significantly associated with a } \\
\text { poor outcome in CM and could be used to } \\
\text { determine mortality risk in patients }\end{array}$ & Wilson et al., 2011 \\
\hline Soluble ICAM-1 & SICAM-1 & $\begin{array}{l}\text { Endothelial (plasma } \\
\text { levels) }\end{array}$ & ELISA based assays & $\begin{array}{l}\text { High levels of soluble ICAM-1 are strongly } \\
\text { associated with CM }\end{array}$ & Adukpo et al., 2013 \\
\hline $\begin{array}{l}\text { Specific muscle } \\
\text { proteins }\end{array}$ & $\begin{array}{l}\text { CA3 (major), CK, } \\
\text { CKM, MB }\end{array}$ & Vascular (plasma levels) & Affinity-Proteomics & $\begin{array}{l}\text { Elevated levels of specific muscle proteins } \\
\text { in plasma indicate muscle damage and } \\
\text { microvasculature lesions in children with } \\
\text { CM }\end{array}$ & Bachmann et al., 2014 \\
\hline $\begin{array}{l}\text { Pf histidine-rich } \\
\text { protein-2 }\end{array}$ & PfHRP2 & CSF & ELISA based assays & $\begin{array}{l}\text { Elevation of CSF pfHRP- } 2 \text { is indicative of } \\
\text { mortality in CM patients }\end{array}$ & Thakur et al., 2014 \\
\hline \multicolumn{6}{|c|}{ EXPERIMENTAL CEREBRAL MALARIA } \\
\hline Endothelin-1 & ET-1 & Endothelial & $\mathrm{RT} / \mathrm{qRT}$-PCR & $\begin{array}{l}\text { Significant increase of mRNA levels of } \\
\text { ET-1, coding enzyme ECE and its } \\
\text { receptors (ET-A, B) }\end{array}$ & Machado et al., 2006 \\
\hline $\begin{array}{l}\text { Chemokine receptor } \\
\text { CXCR3 and its ligands } \\
\text { (Mig, IP-10) }\end{array}$ & $\begin{array}{l}\text { CXCR3, Mig, } \\
\text { IP-10 }\end{array}$ & N/A & qPCR/ELISA & $\begin{array}{l}\text { CXCR3 is essential for trafficking of T cells } \\
\text { into the brain and the development of } \\
\text { ECM. CXCR3 ligands (Mig and IP-10) have } \\
\text { distinct and non-redundant roles in ECM } \\
\text { pathogenesis }\end{array}$ & Campanella et al., 2008 \\
\hline Glutamate & Glu & Brain & $\begin{array}{l}\text { Enzyme assays, } \\
\text { SHIRPA screen }\end{array}$ & $\begin{array}{l}\text { Increased levels of glutamate leads to } \\
\text { CNS dysfunction, neurological and } \\
\text { behavioral symptoms }\end{array}$ & Miranda et al., 2010 \\
\hline $\begin{array}{l}\text { Cerebral levels of } \mathrm{IL}-1 \beta \\
\text { and TNF }\end{array}$ & IL-1 $\beta$ and TNF & CSF & ELISA based assays & $\begin{array}{l}\text { Increased cerebral levels of IL-1 } \beta \text { and TNF } \\
\text { are associated with anxiety-like behavior }\end{array}$ & Miranda et al., 2010 \\
\hline $\begin{array}{l}\text { CD8+ T Cells and } \\
\text { IFN- } \gamma\end{array}$ & $\begin{array}{l}\text { CD8+ T cells, } \\
\text { IFN- } \gamma\end{array}$ & NA & ELISA based assays & $\begin{array}{l}\text { CD8+ T Cells and IFN-gamma are } \\
\text { required for time-dependent accumulation } \\
\text { of PRBC in deep organs }\end{array}$ & Claser et al., 2011 \\
\hline
\end{tabular}


TABLE 1 | Continued

\begin{tabular}{|c|c|c|c|c|c|}
\hline Biomarker & Abbreviations & Type/Site & Method & Indicative events & Study \\
\hline $\begin{array}{l}\text { Granzyme B } \\
\text { expression }\end{array}$ & GzmB & CD8+ T cells & $\begin{array}{l}\text { gzmB } B^{-/-} \text {knock out } \\
\text { mice }\end{array}$ & $\begin{array}{l}\text { High expression of Granzyme B on CD8+ } \\
T \text { cells reduces parasite biomass in the } \\
\text { brain; ECM induction is dependent on } \\
\text { antiparasitic CD4+ T cell responses }\end{array}$ & Haque et al., 2011 \\
\hline $\begin{array}{l}\text { Platelet Activating } \\
\text { Factor }\end{array}$ & PAF & Endothelial & $\begin{array}{l}\mathrm{PAFR}^{-/}-\text {knock out } \\
\text { mice }\end{array}$ & $\begin{array}{l}\text { Facilitates the recruitment of leukocytes, } \\
\text { induces the release of immune factors; } \\
\text { increases vascular permeability }\end{array}$ & $\begin{array}{l}\text { Lacerda-Queiroz et al., } \\
2012\end{array}$ \\
\hline $\begin{array}{l}\text { Brain water channel } \\
\text { aquaporin-4 }\end{array}$ & AQP4 & CSF & $\begin{array}{l}\text { Semi-quantitative } \\
\text { RT-PCR }\end{array}$ & Partial protection conferred by AQP4 & Promeneur et al., 2013 \\
\hline Plasma microparticles & MP & Blood & Biochemical & $\begin{array}{l}\text { Mediates coagulation, inflammation, and } \\
\text { cell adhesion; facilitates neurological } \\
\text { lesions }\end{array}$ & El-Assaad et al., 2014b \\
\hline
\end{tabular}

Epo, erythropoietin; PfEMP-1, Plasmodium falciparum Erythrocyte Membrane Protein-1; AQP4, Aquaporin 4; ECM, experimental CM.

the disease outcome, as recently demonstrated in retinopathy positive CM patients from Malawi. Using $100 \mathrm{CSF}$ and 103 plasma samples, their findings inferred that an increased level of PfHRP2 in CSF and lower plasma/CSF PfHRP2 ratios was predictive of death in retinopathy positive CM patients (Thakur et al., 2014).

\section{Future Directions and Market Barriers}

Host plasma microparticles (MP) are submicron elements $(100 \mathrm{~nm}-1 \mu \mathrm{M})$, which originate from extracellular vesiculation processes during host cell activation and/or apoptotic events. High MP numbers were shown to be significantly higher in the plasma of patients with CM compared to patients with uncomplicated malaria or severe anemia in several separate analyses (Combes et al., 2004; Pankoui Mfonkeu et al., 2010; Nantakomol et al., 2011), showing that they could be potentially used as a diagnosis biomarker for CM. In addition, plateletderived MP were shown to be the most abundant in the plasma of CM patients, and their levels were significantly correlated with coma depth and thrombocytopenia. However, the current analysis of plasma MP necessitate high-sensitivity clinical equipment and trained technicians, which might explain why their use as a biomarker in endemic regions has not been further investigated to date. The fast-paced evolution of low-cost, portable, point-of care quantitative diagnostic devices might reverse the situation in the near future. Similarly, cumulating data suggest that small non-coding-RNAs such as microRNAs (miRNAs) can be utilized as potential biomarkers for the diagnosis and prognosis of a variety of parasitic diseases (Manzano-Roman and Siles-Lucas, 2012). Circulating miRNAs can be detected in biological fluids as serum, saliva and others, exhibiting a good potential as non-invasive biomarkers. While this has not yet been evaluated in falciparum malaria infection, it is likely that the current technology required for miRNA identification and quantification will restrict their use as diagnostic or prognosis biomarker for now. Lastly, In addition to biomarkers from biological media, the recent implementation of MRI techniques to investigate the factors leading to the development of CM might also lead to the identification of biomarkers of severity and/or disease outcome using imaging maps. Such approaches could focus on the parasite burden in the brain and correlate it with disease severity, or establish a scale of brain swelling in CM patients, potentially indicative of the disease prognosis.

\section{EMERGING THERAPEUTIC OPTIONS}

The major challenge to prevent human mortality in CM lies in the current lack of specific therapies aimed at dampening the proinflammatory state associated with the neurologic syndrome, as well as its deleterious effects on the host. Considering the multifactorial nature of the neuropathology, even the most effective anti malarial drugs cannot ensure complete survival (Dondorp et al., 2005, 2010; Mishra and Wiese, 2009) and due to the poor understanding of its pathogenic processes, candidate adjunctive therapies to decrease mortality in CM have been unsuccessful so far (Mohanty et al., 2006, 2011; Mishra and Wiese, 2009; John et al., 2010). However, the recent breakthrough allowed by some of the technologies and approaches described above are slowly narrowing the spectrum of candidate therapeutic pathways. Table 2 represents some of the potential therapeutics against $\mathrm{CM}$, based on recent observations from experimental models and human pathogenesis. Some of these novel adjunct therapies include heme-oxygenase-1 (HO-1) and carbon monoxide (CO), exogenous nitric oxide, pressurized oxygen, additive antioxidants, and hydrogen sulfide gas (Dellavalle et al., 2013; Table 2).

In addition to adjunct therapies, new classes of agents developed using novel creative strategies are urgently needed to tackle severe malaria infection. Indeed, the number of available and effective antimalarial drugs is quickly dwindling, as the resistance of $P$. falciparum against artemisinin combination treatments (ACT), the recommended first-line therapy for infected patients, is now prevalent across mainland Southeast Asia (Ashley et al., 2014). This is alarming because: (i) resistance to the previous mainstays of antimalarial treatments-namely 


\section{POSTCAPILLARY VENULE}

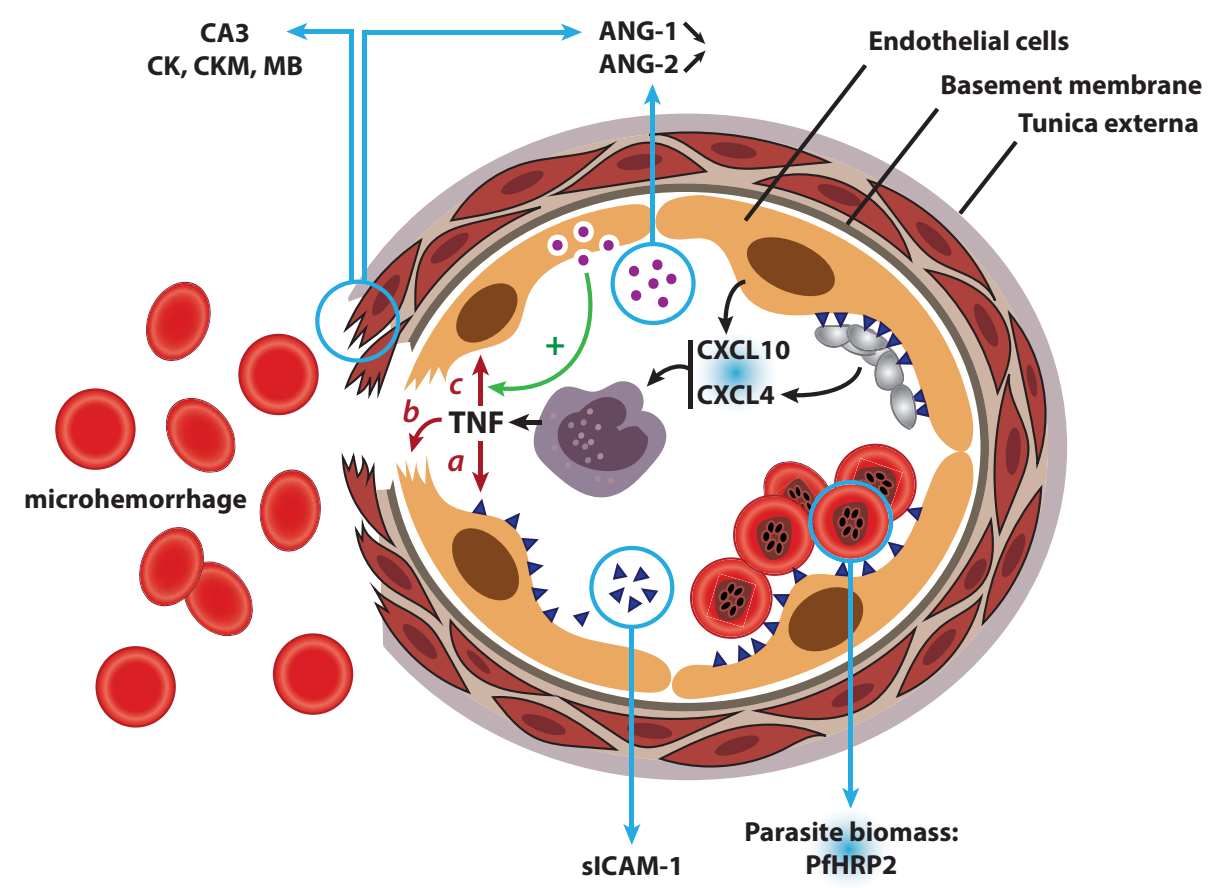

\begin{tabular}{|lll|}
\hline PRBC & Platelets & Smooth muscle cells \\
\hline Marker of pathology & Marker of poor outcome \\
\hline
\end{tabular}

FIGURE 1 | Links between human CM physiopathology and current biomarkers of pathogenesis and poor outcome: a proposed model. Upon infection with $P$. falciparum, the host immune system produces pro-inflammatory cytokines, which activate endothelial cells, prompting them to produce CXCL10, a chemoattractant for mononuclear leukocytes. Platelets accumulated in the microvasculature of CM patients release CXCL4 from their alpha granules, which stimulates the production of TNF by mononuclear leukocytes locally. Both cytokines contribute to a hyperinflammatory state in CM and are associated with a poor outcome. Once released, TNF leads to the upregulation of ICAM-1 on endothelial cells (a), which, in turn, induces the sequestration of PRBC and platelets in the cerebral microvasculature. The presence of soluble ICAM-1 in the plasma is reflective of the increase in ICAM-1 levels at the endothelial surface. High densities of sequestered parasites produce elevated amounts of PfHRP2, a marker of pathology and an indicator of poor outcome when detected in the CSF. Sequestration of parasites, coupled with high levels of TNF induce focal vascular injuries, leading to smooth muscle cell damage and ring hemorrhages (b). Injured smooth muscle cells discharge abnormally high amounts of carbonic anhydrase III (CA3), creatine kinase (CK), creatine kinase, muscle (CKM), and myoglobin (MB) in the bloodstream, all biomarkers of CM. In addition, destroyed smooth muscle cells stop producing ANG-1, contributing to its systemic decrease. Coupled with an elevated release of ANG-2 from the Weibel-Palade bodies of activated endothelial cells, the shift in the angiogenic factor balance results in a high ANG-2:ANG-1 ratio, another marker of pathology. ANG-2 sensitizes endothelial cells, which become responsive to sub-threshold concentrations of TNF, contributing to the aggravation of the different pathways described above (c).

chloroquine and sulfadoxine/pyrimethamine-have already spread across southeast Asia into Africa, resulting in the deaths of millions of patients (Roper et al., 2004) and (ii) there are currently no alternative drugs to replace ACT. However, unprecedented global and multidisciplinary efforts aimed at broadening therapeutic potential and identifying novel modes of action are currently in place (Flannery et al., 2013). Hopefully, these efforts will allow the widening of malaria treatement options and will help to overcome the emerging drug resistance.

\section{CONCLUDING REMARKS}

The World Health Organization estimated that deaths related to malaria have dropped down from one million in 2000 to about 780,000 in 2009 and 627,000 in 2013 (W.H.O., 2011, 2014). In endemic Africa, unprecedented levels of intervention coverage have halved Plasmodium falciparum infection prevalence since 2000 , and the incidence of clinical disease have dropped by $40 \%$ (Bhatt et al., 2015). Despite this promising trend, the figures 
TABLE 2 | Cerebral malaria: emerging therapeutic options.

\begin{tabular}{|c|c|c|c|c|}
\hline Therapeutics & Mode & Observation/mechanism of protection & References & Stage \\
\hline \multicolumn{5}{|c|}{ HUMAN CEREBRAL MALARIA } \\
\hline Levetiracetam (LVT1) & Single & $\begin{array}{l}\text { Treatment of seizures, epilepsy and improves CM } \\
\text { outcome in African children }\end{array}$ & $\begin{array}{l}\text { http://www.clinicaltrials. } \\
\text { gov/ct2/show/study/ } \\
\text { NCT01660672 }\end{array}$ & $\begin{array}{l}\text { Clinical trial completed, } \\
\text { Oct } 2014\end{array}$ \\
\hline Rosiglitazone & AP-partnered & $\begin{array}{l}\text { Decreases levels of pro-inflammatory factors (IL-6 and } \\
\text { MCP-1); elevates BDNF levels (day 2) and lowers } \\
\text { Ang-2/Ang-1 ratio (day 3) }\end{array}$ & Serghides et al., 2014 & In vivo study \\
\hline \multicolumn{5}{|c|}{ EXPERIMENTAL CEREBRAL MALARIA } \\
\hline $\begin{array}{l}\text { Heme-Oxygenase- } 1 \\
(\mathrm{HO}-1) \text { and carbon } \\
\text { monoxide }(\mathrm{CO})\end{array}$ & Adjunctive & $\begin{array}{l}\text { Decreases parasitemia, prevents BBB disruption, brain } \\
\text { microvasculature congestion, neuro-inflammation and } \\
\text { CD8+ T-cell brain sequestration during ECM }\end{array}$ & Pamplona et al., 2007 & Experimental \\
\hline $\begin{array}{l}\text { Pressurized oxygen } \\
\text { (HBO) therapy }\end{array}$ & Adjunctive & $\begin{array}{l}\text { Prevents ECM signs; reduces expression of TNF, IFN- } \gamma \\
\text { and IL-10 mRNA levels and percentage of } \gamma \delta \text { and } \alpha \beta \\
\text { CD4+ and CD } 8+T \text { cell sequestration, prevents BBB } \\
\text { dysfunction }\end{array}$ & Blanco et al., 2008 & Experimental \\
\hline Thiol Pantethine & Adjunctive & $\begin{array}{l}\text { Decreases circulating microparticles and protects BBB } \\
\text { integrity }\end{array}$ & Penet et al., 2008 & Experimental \\
\hline Nimodipine & $\begin{array}{l}\text { Artemether- } \\
\text { partnered }\end{array}$ & $\begin{array}{l}\text { Prevents vasoconstriction and vascular collapse by } \\
\text { inducing vasodilation and enhancing pial blood flow; } \\
\text { increases survival }\end{array}$ & Cabrales et al., 2010 & Experimental \\
\hline Artemisone & CQ-partnered & Prevents mortality at late stages of ECM & $\begin{array}{l}\text { Waknine-Grinberg et al., } \\
2010\end{array}$ & Experimental \\
\hline Antioxidant therapy & CQ-partnered & $\begin{array}{l}\text { Prevents the development of persistent cognitive } \\
\text { damage }\end{array}$ & Reis et al., 2010 & Experimental \\
\hline Flt3 ligand & Adjunctive & $\begin{array}{l}\text { Helps reducing the proportion of CD8-T cells producing } \\
\text { IFN- } \gamma \text { and granzyme B; decreases sequestration of } \\
\text { PRBC }\end{array}$ & Tamura et al., 2011 & Experimental \\
\hline $\begin{array}{l}\text { Artemether }+ \\
\text { Artesunate }\end{array}$ & Combinative & $\begin{array}{l}\text { Prevents death at late-stages of ECM; reduces leukocyte } \\
\text { accumulation in brain vessels and decreases cerebral } \\
\text { vascular inflammation }\end{array}$ & Clemmer et al., 2011 & Experimental \\
\hline $\begin{array}{l}\text { Exogenous Nitric Oxide } \\
\text { (NO) }\end{array}$ & Single & $\begin{array}{l}\text { Leads to a decreased expression of ICAM-1 and } \\
\text { P-selectin; a lower number of adherent leukocytes and } \\
\text { platelets in pial vessels and in venules; a reduced } \\
\text { vascular inflammation, and albumin leakage }\end{array}$ & Zanini et al., 2011 & Experimental \\
\hline Erythropoietin & Single & $\begin{array}{l}\text { Reverses the development of ECM and degree of neural } \\
\text { hypoxia; reduces clinical signs of CM and cerebral } \\
\text { pathology features }\end{array}$ & Hempel et al., 2011, 2012 & Experimental \\
\hline HJP-272 & $\begin{array}{l}\text { Artemether- } \\
\text { partnered }\end{array}$ & Decreases brain hemorrhage and increases survival & Dai et al., 2012 & Experimental \\
\hline IDR-peptide & Adjunctive & $\begin{array}{l}\text { Enhances mice survival in late stage interventions } \\
\text { through anti-inflammatory networks }\end{array}$ & Achtman et al., 2012 & Experimental \\
\hline Atorvastatin & Adjunctive & $\begin{array}{l}\text { Prevents parasite cytoadherence and endothelial } \\
\text { damage; enhances the pharmacologic inhibition of } \\
\text { CXCL10 and a reduction in mortality }\end{array}$ & $\begin{array}{l}\text { Taoufiq et al., 2011; } \\
\text { Wilson et al., } 2011\end{array}$ & Experimental \\
\hline Rosiglitazone & Adjunctive & $\begin{array}{l}\text { As an agonist of Peroxisome proliferator-activated } \\
\text { receptor- } \gamma(\text { PPAR- } \gamma \text { ), modulates host inflammatory } \\
\text { responses and improves clinical outcome in ECM; } \\
\text { prevents the development of brain atrophy and } \\
\text { neurocognitive impairment }\end{array}$ & $\begin{array}{l}\text { Serghides et al., 2009, } \\
2014\end{array}$ & Experimental \\
\hline
\end{tabular}


TABLE 2 | Continued

\begin{tabular}{|c|c|c|c|c|}
\hline Therapeutics & Mode & Observation/mechanism of protection & References & Stage \\
\hline Neuregulin-1 (NRG-1) & $\begin{array}{l}\text { Single; Compared } \\
\text { with Artemether }\end{array}$ & $\begin{array}{l}\text { Leads to endothelial protection and reduction in BBB } \\
\text { permeability; neuro-protective nature, decreases } \\
\text { mortality }\end{array}$ & $\begin{array}{l}\text { Li et al., 2012; Lok et al., } \\
\text { 2012; Solomon et al., } \\
2014\end{array}$ & Experimental \\
\hline Citicoline (CTC) & Adjunctive & $\begin{array}{l}\text { CTC reduces the production of microparticles in vitro; } \\
\text { confers protection against ECM }\end{array}$ & El-Assaad et al., 2014a & Experimental \\
\hline
\end{tabular}

BBB, blood-brain barrier; ECM, experimental CM; IDR-peptide, innate defense regulatory peptide; CQ, Chloroquine; AP, Atovaquone-Proguanil; BDNF, brain-derived neurotrophic factor.

are still worrisome. Such progress has been possible despite the lack of a malaria vaccine and is mainly attributable to increased prevention efforts globally, coupled to the widespread use of artemesinin derivatives. The systematic use of some of the emerging new technologies aimed at facilitating the early and accurate diagnosis of malaria-associated complications is likely to not only help clinicians identify high-risk CM patients in the future, but also expedite the clinical triage of symptomatic parasitemic patients, as well as their prompt and comprehensive care. This will, hopefully, lead to a further decrease in malaria-related deaths worldwide. In addition, the recent implementation of state-of-the-art investigation tools to elucidate the pathophysiology of CM is also likely to contribute to the identification of new image-derived prognosis biomarkers and adjunct therapeutic avenues, as illustrated by the recent and groundbreaking study of brain lesions in Malawian patients with CM (Seydel et al., 2015). Lastly, the European Medicines Agency just approved the RTS,S vaccine with the recommendation that it should be used in African children at risk, the first malaria vaccine to ever get this clearance (Hawkes, 2015). Coupled with

\section{REFERENCES}

Achtman, A. H., Pilat, S., Law, C. W., Lynn, D. J., Janot, L., Mayer, M. L., et al. (2012). Effective adjunctive therapy by an innate defense regulatory peptide in a preclinical model of severe malaria. Sci. Transl. Med. 4:135ra164. doi: 10.1126/scitranslmed.3003515

Adukpo, S., Kusi, K. A., Ofori, M. F., Tetteh, J. K., Amoako-Sakyi, D., Goka, B. Q., et al. (2013). High plasma levels of soluble intercellular adhesion molecule (ICAM)-1 are associated with cerebral malaria. PLOS ONE 8:e84181. doi: 10.1371/journal.pone.0084181

Ashley, E. A., Dhorda, M., Fairhurst, R. M., Amaratunga, C., Lim, P., Suon, S., et al. (2014). Spread of artemisinin resistance in Plasmodium falciparum malaria. $N$. Engl. J. Med. 371, 411-423. doi: 10.1056/NEJMoa1314981

Bachmann, J., Burte, F., Pramana, S., Conte, I., Brown, B. J., Orimadegun, A. E., et al. (2014). Affinity proteomics reveals elevated muscle proteins in plasma of children with cerebral malaria. PLoS Pathog. 10:e1004038. doi: 10.1371/journal.ppat. 1004038

Beare, N. A., Harding, S. P., Taylor, T. E., Lewallen, S., and Molyneux, M. E. (2009). Perfusion abnormalities in children with cerebral malaria and malarial retinopathy. J. Infect. Dis. 199, 263-271. doi: 10.1086/595735

Beare, N. A., Southern, C., Chalira, C., Taylor, T. E., Molyneux, M. E., and Harding, S. P. (2004). Prognostic significance and course of retinopathy in children with severe malaria. Arch. Ophthalmol. 122, 1141-1147. doi: 10.1001/archopht.122.8.1141

Beare, N. A., Taylor, T. E., Harding, S. P., Lewallen, S., and Molyneux, M. E. (2006). Malarial retinopathy: a newly established diagnostic sign in severe malaria. Am. J. Trop. Med. Hyg. 75, 790-797. doi: 10.1016/j.idcr.2014.10.003 the clinical efforts in malaria-endemic regions, this vaccine could represent a milestone in the global fight against malaria.

\section{FUNDING}

This work was supported by the National Institute of Allergy and Infectious Diseases, National Institutes of Health, grant U19AI089676-01S1 (to SCW). The content is solely the responsibility of the authors and does not necessarily represent the official views of the National Institutes of Health.

\section{ACKNOWLEDGMENTS}

The authors wish to dedicate this Review to the memory of Dr. Saroj Kanti Mishra. Dr. Mishra was a pioneer clinician scientist in the field of severe malaria and an inspiration for his peers. His contributions to tropical medicine, and to the management of cerebral malaria in particular, saved the lives of many. He will be sorely missed.

Berendt, A. R., Tumer, G. D., and Newbold, C. I. (1994). Cerebral malaria: the sequestration hypothesis. Parasitol. Today 10, 412-414. doi: 10.1016/01694758(94)90238-0

Bhatt, S., Weiss, D. J., Cameron, E., Bisanzio, D., Mappin, B., Dalrymple, U., et al. (2015). The effect of malaria control on Plasmodium falciparum in Africa between 2000 and 2015. Nature. doi: 10.1038/nature15535

Birbeck, G. L., Molyneux, M. E., Kaplan, P. W., Seydel, K. B., Chimalizeni, Y. F., Kawaza, K., et al. (2010). Blantyre Malaria Project Epilepsy Study (BMPES) of neurological outcomes in retinopathy-positive paediatric cerebral malaria survivors: a prospective cohort study. Lancet Neurol. 9, 1173-1181. doi: 10.1016/S1474-4422(10)70270-2

Blanco, Y. C., Farias, A. S., Goelnitz, U., Lopes, S., Arrais-Silva, W. W., Carvalho, B. O., et al. (2008). Hyperbaric oxygen prevents early death caused by experimental cerebral malaria. PLOS ONE 3:e3126. doi: 10.1371/journal.pone.0003126

Bridges, D. J., Bunn, J., van Mourik, J. A., Grau, G., Preston, R. J., Molyneux, M., et al. (2010). Rapid activation of endothelial cells enables Plasmodium falciparum adhesion to platelet-decorated von Willebrand factor strings. Blood 115, 1472-1474. doi: 10.1182/blood-2009-07-235150

Cabrales, P., Martins, Y. C., Ong, P. K., Zanini, G. M., Frangos, J. A., and Carvalho, L. J. (2013). Cerebral tissue oxygenation impairment during experimental cerebral malaria. Virulence 4, 686-697. doi: 10.4161/viru.26348

Cabrales, P., Zanini, G. M., Meays, D., Frangos, J. A., and Carvalho, L. J. (2010). Murine cerebral malaria is associated with a vasospasm-like microcirculatory dysfunction, and survival upon rescue treatment is markedly increased by nimodipine. Am. J. Pathol. 176, 1306-1315. doi: 10.2353/ajpath.2010. 090691 
Cabrales, P., Zanini, G. M., Meays, D., Frangos, J. A., and Carvalho, L. J. (2011). Nitric oxide protection against murine cerebral malaria is associated with improved cerebral microcirculatory physiology. J. Infect. Dis. 203, 1454-1463. doi: 10.1093/infdis/jir058

Campanella, G. S., Tager, A. M., El Khoury, J. K., Thomas, S. Y., Abrazinski, T. A., Manice, L. A., et al. (2008). Chemokine receptor CXCR3 and its ligands CXCL9 and CXCL10 are required for the development of murine cerebral malaria. Proc. Natl. Acad. Sci. U.S.A. 105, 4814-4819. doi: 10.1073/pnas.0801544105

Carter, J. A., Neville, B. G., White, S., Ross, A. J., Otieno, G., Mturi, N., et al. (2004). Increased prevalence of epilepsy associated with severe falciparum malaria in children. Epilepsia 45, 978-981. doi: 10.1111/j.0013-9580.2004.65103.x

Casals-Pascual, C., Idro, R., Gicheru, N., Gwer, S., Kitsao, B., Gitau, E., et al. (2008). High levels of erythropoietin are associated with protection against neurological sequelae in African children with cerebral malaria. Proc. Natl. Acad. Sci. U.S.A. 105, 2634-2639. doi: 10.1073/pnas.0709715105

Clark, I. A., and Rockett, K. A. (1994). The cytokine theory of human cerebral malaria. Parasitol. Today 10, 410-412. doi: 10.1016/0169-4758(94)90237-2

Claser, C., Malleret, B., Gun, S. Y., Wong, A. Y. W., Chang, Z. W., Teo, P., et al. (2011). CD8+ T cells and IFN- $\gamma$ mediate the time-dependent accumulation of infected red blood cells in deep organs during experimental cerebral malaria. PLoS ONE 6:e18720. doi: 10.1371/journal.pone.0018720

Clemmer, L., Martins, Y., Zanini, G., Frangos, J., and Carvalho, L. (2011). Artemether and artesunate show the highest efficacies in rescuing mice with late-stage cerebral malaria and rapidly decrease leukocyte accumulation in the brain. Antimicrob. Agents Chemother. 55, 1383-1390. doi: 10.1128/AAC.01 277-10

Combes, V., Taylor, T. E., Juhan-Vague, I., Mège, J.-L., Mwenechanya, J., Tembo, M., et al. (2004). Circulating endothelial microparticles in malawian children with severe falciparum malaria complicated with coma. JAMA 291, 2542-2544. doi: 10.1001/jama.291.21.2542-b

Conroy, A. L., Lafferty, E. I., Lovegrove, F. E., Krudsood, S., Tangpukdee, N., Liles, W. C., et al. (2009). Whole blood angiopoietin-1 and -2 levels discriminate cerebral and severe (non-cerebral) malaria from uncomplicated malaria. Malar. J. 8:295. doi: 10.1186/1475-2875-8-295

Conroy, A. L., Phiri, H., Hawkes, M., Glover, S., Mallewa, M., Seydel, K. B., et al. (2010). Endothelium-based biomarkers are associated with cerebral malaria in Malawian children: a retrospective case-control study. PLoS ONE 5:e15291. doi: 10.1371/journal.pone.0015291

Craig, A. G., Grau, G. E., Janse, C., Kazura, J. W., Milner, D., Barnwell, J. W., et al. (2012). The role of animal models for research on severe malaria. PLoS Pathog. 8:e1002401-e1002401. doi: 10.1371/journal.ppat.1002401

Crawley, J., Smith, S., Kirkham, F., Muthinji, P., Waruiru, C., and Marsh, K. (1996). Seizures and status epilepticus in childhood cerebral malaria. QJM 89, 591-597. doi: 10.1093/qjmed/89.8.591

Dai, M., Freeman, B., Bruno, F. P., Shikani, H. J., Tanowitz, H. B., Weiss, L. M., et al. (2012). The novel ETA receptor antagonist HJP-272 prevents cerebral microvascular hemorrhage in cerebral malaria and synergistically improves survival in combination with an artemisinin derivative. Life Sci. 91, 687-692. doi: 10.1016/j.lfs.2012.07.006

Dellavalle, B., Staalsoe, T., Kurtzhals, J. A. L., and Hempel, C. (2013). Investigation of hydrogen sulfide gas as a treatment against $P$. falciparum, murine cerebral malaria, and the importance of thiolation state in the development of cerebral malaria. PloS ONE 8:e59271. doi: 10.1371/journal.pone.0059271

Dondorp, A. M., Fanello, C. I., Hendriksen, I. C., Gomes, E., Seni, A., Chhaganlal, K. D., et al. (2010). Artesunate versus quinine in the treatment of severe falciparum malaria in African children (AQUAMAT): an open-label, randomised trial. Lancet 376, 1647-1657. doi: 10.1016/S0140-6736(10)61924-1

Dondorp, A., Nosten, F., Stepniewska, K., Day, N., White, N., and South East Asian Quinine Artesunate Malaria Trial, G. (2005). Artesunate versus quinine for treatment of severe falciparum malaria: a randomised trial. Lancet 366, 717-725. doi: 10.1016/S0140-6736(05)67176-0

Dorovini-Zis, K., Schmidt, K., Huynh, H., Fu, W., Whitten, R. O., Milner, D., et al. (2011). The neuropathology of fatal cerebral malaria in malawian children. Am. J. Pathol. 178, 2146-2158. doi: 10.1016/j.ajpath.2011.01.016

El-Assaad, F., Combes, V., Grau, G. E. R., and Jambou, R. (2014a). Potential Efficacy of Citicoline as Adjunct Therapy in Treatment of Cerebral Malaria. Antimicrob. Agents Chemother. 58, 602-605. doi: 10.1128/AAC.02591-12

El-Assaad, F., Wheway, J., Hunt, N. H., Grau, G., and Combes, V. (2014b). Production, fate and pathogenicity of plasma microparticles in murine cerebral malaria. PLoS Pathog. 10:e1003839. doi: 10.1371/journal.ppat. 1003839

Ellis, C. G., Jagger, J., and Sharpe, M. (2005). The microcirculation as a functional system. Crit. Care 9(Suppl. 4), S3-S8. doi: 10.1186/cc3751

Flannery, E. L., Chatterjee, A. K., and Winzeler, E. A. (2013). Antimalarial drug discovery - approaches and progress towards new medicines. Nat. Rev. Microbiol. 11, 849-862. doi: 10.1038/nrmicro3138

Franke-Fayard, B., Djokovic, D., Dooren, M. W., Ramesar, J., Waters, A. P., Falade, M. O., et al. (2008). Simple and sensitive antimalarial drug screening in vitro and in vivo using transgenic luciferase expressing Plasmodium berghei parasites. Int. J. Parasitol. 38, 1651-1662. doi: 10.1016/j.ijpara.2008.05.012

Franke-Fayard, B., Waters, A. P., and Janse, C. J. (2006). Real-time in vivo imaging of transgenic bioluminescent blood stages of rodent malaria parasites in mice. Nat. Protoc. 1, 476-485. doi: 10.1038/nprot.2006.69

Fraz, M. M., Remagnino, P., Hoppe, A., Uyyanonvara, B., Rudnicka, A. R., Owen, C. G., et al. (2012). Blood vessel segmentation methodologies in retinal images - a survey. Comput. Methods Progr. Biomed. 108, 407-433. doi: 10.1016/j.cmpb.2012.03.009

Frevert, U., Nacer, A., Cabrera, M., Movila, A., and Leberl, M. (2014). Imaging Plasmodium immunobiology in the liver, brain, and lung. Parasitol. Int. 63, 171-186. doi: 10.1016/j.parint.2013.09.013

Grant, A. C., Abdel-Baki, S. G., Omurtag, A., Sinert, R., Chari, G., Malhotra, S., et al. (2014). Diagnostic accuracy of microEEG: a miniature, wireless EEG device. Epilepsy Behav. 34, 81-85. doi: 10.1016/j.yebeh.2014.03.015

Grau, G. E., Mackenzie, C. D., Carr, R. A., Redard, M., Pizzolato, G., Allasia, C., et al. (2003). Platelet accumulation in brain microvessels in fatal pediatric cerebral malaria. J. Infect. Dis. 187, 461-466. doi: 10.1086/367960

Haque, A., Best, S. E., Unosson, K., Amante, F. H., De Labastida, F., Anstey, N. M., et al. (2011). Granzyme B expression by CD8+ T cells is required for the development of experimental cerebral malaria. J. Immunol. 186, 6148-6156. doi: 10.4049/jimmunol.1003955

Hawkes, M., Elphinstone, R. E., Conroy, A. L., and Kain, K. C. (2013). Contrasting pediatric and adult cerebral malaria: the role of the endothelial barrier. Virulence 4, 543-555. doi: 10.4161/viru.25949

Hawkes, N. (2015). European Medicines Agency approves first malaria vaccine. BMJ 351:h4067. doi: 10.1136/bmj.h4067

Hempel, C., Combes, V., Hunt, N. H., Kurtzhals, J. A. L., and Grau, G. E. R. (2011). CNS hypoxia is more pronounced in murine cerebral than noncerebral malaria and is reversed by erythropoietin. Am. J. Pathol. 179, 1939-1950. doi: 10.1016/j.ajpath.2011.06.027

Hempel, C., Hyttel, P., Staalso, T., Nyengaard, J. R., and Kurtzhals, J. A. (2012). Erythropoietin treatment alleviates ultrastructural myelin changes induced by murine cerebral malaria. Malar. J. 11:216. doi: 10.1186/1475-2875-11-216

Hendriksen, I. C., Mwanga-Amumpaire, J., von Seidlein, L., Mtove, G., White, L. J., Olaosebikan, R., et al. (2012). Diagnosing severe falciparum malaria in parasitaemic African children: a prospective evaluation of plasma PfHRP2 measurement. PLoS Med. 9:e1001297. doi: 10.1371/journal.pmed.1001297

Hollestelle, M. J., Donkor, C., Mantey, E. A., Chakravorty, S. J., Craig, A., Akoto, A. O., et al. (2006). von Willebrand factor propeptide in malaria: evidence of acute endothelial cell activation. Br. J. Haematol. 133, 562-569. doi: 10.1111/j.13652141.2006.06067.x

Huang, L. L., and Hirose, T. (2012). Portable optical coherence tomography in management of vitreoretinal diseases: current developments, indications, and implications. Semin. Ophthalmol. 27, 213-220. doi: 10.3109/08820538.2012. 708811

Imai, T., Iwawaki, T., Akai, R., Suzue, K., Hirai, M., Taniguchi, T., et al. (2014). Evaluating experimental cerebral malaria using oxidative stress indicator OKD48 mice. Int. J. Parasitol. 44, 681-685. doi: 10.1016/j.ijpara.2014. 06.002

Imwong, M., Woodrow, C. J., Hendriksen, I. C., Veenemans, J., Verhoef, H., Faiz, M. A., et al. (2015). Plasma concentration of parasite DNA as a measure of disease severity in falciparum malaria. J. Infect. Dis. 211, 1128-1133. doi: 10.1093/infdis/jiu590

Jain, V., Armah, H. B., Tongren, J. E., Ned, R. M., Wilson, N. O., Crawford, S., et al. (2008). Plasma IP-10, apoptotic and angiogenic factors associated with fatal cerebral malaria in India. Malar. J. 7:83. doi: 10.1186/1475-2875-7-83

Jain, V., Lucchi, N. W., Wilson, N. O., Blackstock, A. J., Nagpal, A. C., Joel, P. K., et al. (2011). Plasma levels of angiopoietin-1 and -2 predict cerebral malaria outcome in Central India. Malar J. 10:383. doi: 10.1186/1475-2875-10-383 
John, C. C., Kutamba, E., Mugarura, K., and Opoka, R. O. (2010). Adjunctive therapy for cerebral malaria and other severe forms of Plasmodium falciparum malaria. Expert. Rev. Anti. Infect. Ther. 8, 997-1008. doi: 10.1586/eri.10.90

Kariuki, S. M., Gitau, E., Gwer, S., Karanja, H. K., Chengo, E., Kazungu, M., et al. (2014). Value of Plasmodium falciparum histidine-rich protein 2 level and malaria retinopathy in distinguishing cerebral malaria from other acute encephalopathies in Kenyan children. J. Infect. Dis. 209, 600-609. doi: 10.1093/infdis/jit500

Kawai, S., and Sugiyama, M. (2010). Imaging analysis of the brain in a primate model of cerebral malaria. Acta Trop. 114, 152-156. doi: 10.1016/j.actatropica.2009.04.015

Kennan, R. P., Machado, F. S., Lee, S. C., Desruisseaux, M. S., Wittner, M., Tsuji, M., et al. (2005). Reduced cerebral blood flow and $\mathrm{N}$-acetyl aspartate in a murine model of cerebral malaria. Parasitol. Res. 96, 302-307. doi: 10.1007/s00436-005$1349-\mathrm{z}$

Kim, H., Higgins, S., Liles, W. C., and Kain, K. C. (2011). Endothelial activation and dysregulation in malaria: a potential target for novel therapeutics. Curr. Opin. Hematol. 18, 177-185. doi: 10.1097/MOH.0b013e328345a4cf

Kumar, S., Wang, E.-H., Pokabla, M. J., and Noecker, R. J. (2012). Teleophthalmology assessment of diabetic retinopathy fundus images: smartphone versus standard office computer workstation. Telemed. J. E Health 18, 158-162. doi: 10.1089/tmj.2011.0089

Lacerda-Queiroz, N., Rodrigues, D. H., Vilela, M. C., Rachid, M. A., Soriani, F. M., Sousa, L. P., et al. (2012). Platelet-activating factor receptor is essential for the development of experimental cerebral malaria. Am. J. Pathol. 180, 246-255. doi: 10.1016/j.ajpath.2011.09.038

Lee, J. H., Chin, H. S., Chung, M.-H., and Moon, Y. S. (2010). Retinal hemorrhage in Plasmodium vivax malaria. Am. J. Trop. Med. Hyg. 82, 219-222. doi: 10.4269/ajtmh.2010.09-0439

Li, Y., Lein, P. J., Liu, C., Bruun, D. A., Giulivi, C., Ford, G. D., et al. (2012). Neuregulin-1 is neuroprotective in a rat model of organophosphateinduced delayed neuronal injury. Toxicol. Appl. Pharmacol. 262, 194-204. doi: 10.1016/j.taap.2012.05.001

Lok, J., Zhao, S., Leung, W., Seo, J. H., Navaratna, D., Wang, X., et al. (2012). Neuregulin-1 effects on endothelial and blood-brain barrier permeability after experimental injury. Transl. Stroke Res. 3, 119-124. doi: 10.1007/s12975-012$0157-\mathrm{x}$

Looareesuwan, S., Warrell, D. A., White, N. J., Sutharasamai, P., Chanthavanich, P., Sundaravej, K., et al. (1983). Do patients with cerebral malaria have cerebral oedema? A computed tomography study. Lancet 1, 434-437. doi: 10.1016/S0140-6736(83)91437-X

Lovegrove, F. E., Tangpukdee, N., Opoka, R. O., Lafferty, E. I., Rajwans, N., Hawkes, M., et al. (2009). Serum angiopoietin-1 and-2 levels discriminate cerebral malaria from uncomplicated malaria and predict clinical outcome in African children. PLoS ONE 4:e4912. doi: 10.1371/journal.pone.0004912

Maamari, R. N., Keenan, J. D., Fletcher, D. A., and Margolis, T. P. (2014). A mobile phone-based retinal camera for portable wide field imaging. Br. J. Ophthalmol. 98, 438-441. doi: 10.1136/bjophthalmol-2013-303797

Maccormick, I. J., Beare, N. A., Taylor, T. E., Barrera, V., White, V. A., Hiscott, P., et al. (2014). Cerebral malaria in children: using the retina to study the brain. Brain 137(Pt 8), 2119-2142. doi: 10.1093/brain/awu001

Machado, F. S., Desruisseaux, M. S., Kennan, R. P., Hetherington, H. P., Wittner, M., Weiss, L. M., et al. (2006). Endothelin in a murine model of cerebral malaria. Exp. Biol. Med. 231, 1176-1181.

Macpherson, G., Warrell, M., White, N., Looareesuwan, S., and Warrell, D. (1985). Human cerebral malaria. A quantitative ultrastructural analysis of parasitized erythrocyte sequestration. Am. J. Pathol. 119, 385.

Manzano-Roman, R., and Siles-Lucas, M. (2012). MicroRNAs in parasitic diseases: potential for diagnosis and targeting. Mol. Biochem. Parasitol. 186, 81-86. doi: 10.1016/j.molbiopara.2012.10.001

Marsh, K., Forster, D., Waruiru, C., Mwangi, I., Winstanley, M., Marsh, V., et al. (1995). Indicators of life-threatening malaria in African children. N. Engl. J. Med.332, 1399-1404. doi: 10.1056/NEJM199505253322102

Maude, R. J., Dondorp, A. M., Sayeed, A. A., Day, N. P., White, N. J., and Beare, N. A. (2009). The eye in cerebral malaria: what can it teach us? Trans. R. Soc. Trop. Med. Hyg. 103, 661-664. doi: 10.1016/j.trstmh.2008.11.003

Maude, R. J., Plewes, K., Dimock, J., and Dondorp, A. M. (2011). Low-cost portable fluorescein angiography. Br. J. Ophthalmol. 95, 1213-1215. doi: 10.1136/bjo.2010.200576
Mikita, K., Thakur, K., Anstey, N. M., Piera, K. A., Pardo, C. A., Weinberg, J. B., et al. (2014). Quantification of Plasmodium falciparum histidine-rich protein-2 in cerebrospinal spinal fluid from cerebral malaria patients. Am. J. Trop. Med. Hyg. 91, 486-492. doi: 10.4269/ajtmh.14-0210

Miller, L. H., Ackerman, H. C., Su, X.-Z., and Wellems, T. E. (2013). Malaria biology and disease pathogenesis: insights for new treatments. Nat. Med. 19, 156-167. doi: 10.1038/nm.3073

Milner, D. A. Jr., Whitten, R. O., Kamiza, S., Carr, R., Liomba, G., Dzamalala, C., et al. (2014). The systemic pathology of cerebral malaria in African children. Front. Cell Infect. Microbiol. 4:104. doi: 10.3389/fcimb.2014.00104

Miranda, A., Vieira, L., Lacerda-Queiroz, N., Souza, A., Rodrigues, D., Vilela, M., et al. (2010). Increased levels of glutamate in the central nervous system are associated with behavioral symptoms in experimental malaria. Braz. J. Med. Biol. Res. 43, 1173-1177. doi: 10.1590/S0100-879X2010007500130

Mishra, S. K., and Newton, C. R. (2009). Diagnosis and management of the neurological complications of falciparum malaria. Nat. Rev. Neurol. 5, 189-198. doi: 10.1038/nrneurol.2009.23

Mishra, S. K., and Wiese, L. (2009). Advances in the management of cerebral malaria in adults. Curr. Opin. Neurol. 22, 302-307. doi: 10.1097/WCO.0b013e32832a323d

Mohanty, S., Mishra, S. K., Patnaik, R., Dutt, A. K., Pradhan, S., Das, B., et al. (2011). Brain swelling and mannitol therapy in adult cerebral malaria: a randomized trial. Clin. Infect. Dis. 53, 349-355. doi: 10.1093/cid/cir405

Mohanty, S., Patel, D., Pati, S., and Mishra, S. (2006). Adjuvant therapy in cerebral malaria. Indian J. Med. Res. 124, 245.

Moxon, C. A., Heyderman, R. S., and Wassmer, S. C. (2009). Dysregulation of coagulation in cerebral malaria. Mol. Biochem. Parasitol. 166, 99-108. doi: 10.1016/j.molbiopara.2009.03.006

Moxon, C. A., Wassmer, S. C., Milner, D. A., Chisala, N. V., Taylor, T. E., Seydel, K. B., et al. (2013). Loss of endothelial protein C receptors links coagulation and inflammation to parasite sequestration in cerebral malaria in African children. Blood 122, 842-851. doi: 10.1182/blood-2013-03-490219

Myung, D., Jais, A., He, L., Blumenkranz, M. S., and Chang, R. T. (2014). 3D printed smartphone indirect lens adapter for rapid, high quality retinal imaging. J. Mob. Technol. Med. 3, 9-15. doi: 10.7309/jmtm.3.1.3

Nacer, A., Movila, A., Sohet, F., Girgis, N. M., Gundra, U. M., Loke, P., et al. (2014). Experimental cerebral malaria pathogenesis-hemodynamics at the blood brain barrier. PLoS Pathog. 10:e1004528. doi: 10.1371/journal.ppat.1004528

Nantakomol, D., Dondorp, A. M., Krudsood, S., Udomsangpetch, R., Pattanapanyasat, K., Combes, V., et al. (2011). Circulating red cellderived microparticles in human malaria. J. Infect. Dis. 203, 700-706. doi: 10.1093/infdis/jiq104

Newton, C. R., Peshu, N., Kendall, B., Kirkham, F. J., Sowunmi, A., Waruiru, C., et al. (1994). Brain swelling and ischaemia in Kenyans with cerebral malaria. Arch. Dis. Child. 70, 281-287. doi: 10.1136/adc.70.4.281

Newton, C., Taylor, T., and Whitten, R. (1998). Pathophysiology of fatal falciparum malaria in African children. Am. J. Trop. Med. Hyg. 58, 673-683.

Ngoungou, E. B., Dulac, O., Poudiougou, B., Druet-Cabanac, M., Dicko, A., Mamadou Traore, A., et al. (2006). Epilepsy as a consequence of cerebral malaria in area in which malaria is endemic in Mali, West Africa. Epilepsia 47, 873-879.

Omurtag, A., and Fenton, A. A. (2012). Assessing diagnostic tests: how to correct for the combined effects of interpretation and reference standard. PLOS ONE 7:e52221. doi: 10.1371/journal.pone.0052221

Pai, S., Qin, J., Cavanagh, L., Mitchell, A., El-Assaad, F., Jain, R., et al. (2014). Real-time imaging reveals the dynamics of leukocyte behaviour during experimental cerebral malaria pathogenesis. PLoS Pathog. 10:e1004236. doi: 10.1371/journal.ppat.1004236

Pamplona, A., Ferreira, A., Balla, J., Jeney, V., Balla, G., Epiphanio, S., et al. (2007). Heme oxygenase-1 and carbon monoxide suppress the pathogenesis of experimental cerebral malaria. Nat. Med. 13, 703-710. doi: 10.1038/nm1586

Pankoui Mfonkeu, J. B., Gouado, I., Fotso Kuate, H., Zambou, O., Amvam Zollo, P. H., Grau, G. E., et al. (2010). Elevated cell-specific microparticles are a biological marker for cerebral dysfunctions in human severe malaria. PLoS ONE 5:e13415. doi: 10.1371/journal.pone.0013415

Patankar, T. F., Karnad, D. R., Shetty, P. G., Desai, A. P., and Prasad, S. R. (2002). Adult cerebral malaria: prognostic importance of imaging findings and correlation with postmortem findings. Radiology 224, 811-816. doi: 10.1148/radiol.2243010588 
Penet, M. F., Abou-Hamdan, M., Coltel, N., Cornille, E., Grau, G. E., De Reggi, M., et al. (2008). Protection against cerebral malaria by the low-molecularweight thiol pantethine. Proc. Natl. Acad. Sci. U.S.A. 105, 1321-1326. doi: 10.1073/pnas.0706867105

Penet, M. F., Viola, A., Confort-Gouny, S., Le Fur, Y., Duhamel, G., Kober, F., et al. (2005). Imaging experimental cerebral malaria in vivo: significant role of ischemic brain edema. J. Neurosci. 25, 7352-7358. doi: 10.1523/JNEUROSCI. 1002-05.2005

Ponsford, M. J., Medana, I. M., Prapansilp, P., Hien, T. T., Lee, S. J., Dondorp, A. M., et al. (2012). Sequestration and microvascular congestion are associated with coma in human cerebral malaria. J. Infect. Dis. 205, 663-671. doi: 10.1093/infdis/jir812

Potchen, M. J., Birbeck, G. L., Demarco, J. K., Kampondeni, S. D., Beare, N., Molyneux, M. E., et al. (2010). Neuroimaging findings in children with retinopathy-confirmed cerebral malaria. Eur. J. Radiol. 74, 262-268. doi: 10.1016/j.ejrad.2009.02.010

Potchen, M. J., Kampondeni, S. D., Seydel, K. B., Birbeck, G. L., Hammond, C. A., Bradley, W. G., et al. (2012). Acute brain MRI findings in 120 Malawian children with cerebral malaria: new insights into an ancient disease. Am. J. Neuroradiol. 33, 1740-1746. doi: 10.3174/ajnr.A3035

Promeneur, D., Lunde, L. K., Amiry-Moghaddam, M., and Agre, P. (2013). Protective role of brain water channel AQP4 in murine cerebral malaria. Proc. Natl. Acad. Sci. U.S.A. 110, 1035-1040. doi: 10.1073/pnas. 1220566110

Reis, P. A., Comim, C. M., Hermani, F., Silva, B., Barichello, T., Portella, A. C., et al. (2010). Cognitive dysfunction is sustained after rescue therapy in experimental cerebral malaria, and is reduced by additive antioxidant therapy. PLoS Pathog. 6:e1000963. doi: 10.1371/journal.ppat.1000963

Rénia, L., Howland, S. W., Claser, C., Gruner, A. C., Suwanarusk, R., Teo, T.-H., et al. (2012). Cerebral malaria: mysteries at the blood-brain barrier. Virulence 3, 193-201. doi: 10.4161/viru.19013

Roper, C., Pearce, R., Nair, S., Sharp, B., Nosten, F., and Anderson, T. (2004). Intercontinental spread of pyrimethamine-resistant malaria. Science 305, 1124. doi: 10.1126/science.1098876

Sakata, L. M., Deleon-Ortega, J., Sakata, V., and Girkin, C. A. (2009). Optical coherence tomography of the retina and optic nerve - a review. Clin. Exp. Ophthalmol. 37, 90-99. doi: 10.1111/j.1442-9071.2009.02015.x

Sayeed, A. A., Maude, R. J., Hasan, M. U., Mohammed, N., Hoque, M. G., Dondorp, A. M., et al. (2011). Malarial retinopathy in Bangladeshi adults. Am. J. Trop. Med. Hyg. 84, 141-147. doi: 10.4269/ajtmh.2011.10-0205

Serghides, L., McDonald, C. R., Lu, Z., Friedel, M., Cui, C., Ho, K. T., et al. (2014). PPAR $\gamma$ agonists improve survival and neurocognitive outcomes in experimental cerebral malaria and induce neuroprotective pathways in human malaria. PLoS Pathog. 10:e1003980. doi: 10.1371/journal.ppat.1003980

Serghides, L., Patel, S. N., Ayi, K., Lu, Z., Gowda, D. C., Liles, W. C., et al. (2009). Rosiglitazone modulates the innate immune response to Plasmodium falciparum infection and improves outcome in experimental cerebral malaria. J. Infect. Dis. 199, 1536-1545. doi: 10.1086/598222

Seydel, K. B., Kampondeni, S. D., Valim, C., Potchen, M. J., Milner, D. A., Muwalo, F. W., et al. (2015). Brain swelling and death in children with cerebral malaria. N. Engl. J. Med. 372, 1126-1137. doi: 10.1056/NEJMoa1400116

Smith, J. D., Craig, A. G., Kriek, N., Hudson-Taylor, D., Kyes, S., Fagan, T., et al. (2000). Identification of a Plasmodium falciparum intercellular adhesion molecule-1 binding domain: a parasite adhesion trait implicated in cerebral malaria. Proc. Natl. Acad. Sci. U.S.A. 97, 1766-1771. doi: 10.1073/pnas.040545897

Solomon, W., Wilson, N. O., Anderson, L., Pitts, S., Patrickson, J., Liu, M., et al. (2014). Neuregulin-1 attenuates mortality associated with experimental cerebral malaria. J. Neuroinflammation 11. doi: 10.1186/1742-2094-11-9

Spaccapelo, R., Janse, C. J., Caterbi, S., Franke-Fayard, B., Bonilla, J. A., Syphard, L. M., et al. (2010). Plasmepsin 4-deficient Plasmodium berghei are virulence attenuated and induce protective immunity against experimental malaria. Am. J. Pathol. 176, 205-217. doi: 10.2353/ajpath.2010.090504

Sugiyama, M., Ikeda, E., Kawai, S., Higuchi, T., Zhang, H., Khan, N., et al. (2004). Cerebral metabolic reduction in severe malaria: fluorodeoxyglucose-positron emission tomography imaging in a primate model of severe human malaria with cerebral involvement. Am. J. Trop. Med. Hyg. 71, 542-545.

Tamura, T., Kimura, K., Yuda, M., and Yui, K. (2011). Prevention of experimental cerebral malaria by Flt3 ligand during infection with Plasmodium berghei ANKA. Infect. Immun. 79, 3947-3956. doi: 10.1128/IAI.01337-10
Taoufiq, Z., Pino, P., N'dilimabaka, N., Arrouss, I., Assi, S., Soubrier, F., et al. (2011). Atorvastatin prevents Plasmodium falciparum cytoadherence and endothelial damage. Malar. J. 10:52. doi: 10.1186/1475-2875-10-52

Taylor, T. E., Fu, W. J., Carr, R. A., Whitten, R. O., Mueller, J. G., Fosiko, N. G., et al. (2004). Differentiating the pathologies of cerebral malaria by postmortem parasite counts. Nat. Med. 10, 143-145. doi: 10.1038/nm986

Thakur, K., Vareta, J., Carson, K., Taylor, T., Sullivan, D., and Seydel, K. (2014). Performance of Cerebrospinal Fluid (CSF) Plasmodium falciparum HistidineRich Protein-2 (pfHRP-2) in prediction of death in cerebral malaria (S10.007). Neurology 82, S10.007-S010.007.

Thumasupapong, S., Tin, T., Sukontason, K., Sawaddichi, C., and Karbwang, J. (1995). Electroencephalography in cerebral malaria. Southeast Asian J. Trop. Med. Public Health 26, 34-37.

Tokmak, H., Ergonul, O., Demirkol, O., Cetiner, M., and Ferhanoglu, B. (2014). Diagnostic contribution of 18 F-FDG-PET/CT in fever of unknown origin. Int. J. Infect. Dis. 19, 53-58. doi: 10.1016/j.ijid.2013.10.009

Trang, T. T. M., Phu, N. H., Vinh, H., Hien, T. T., Cuong, B. M., Chau, T. T. H., et al. (1992). Acute renal failure in patients with severe falciparum malaria. Clin. Infect. Dis. 15, 874-880. doi: 10.1093/clind/15.5.874

Turner, G. D., Morrison, H., Jones, M., Davis, T. M., Looareesuwan, S., Buley, I. D., et al. (1994). An immunohistochemical study of the pathology of fatal malaria: evidence for widespread endothelial activation and a potential role for intercellular adhesion molecule-1 in cerebral sequestration. Am. J. Pathol. 145, 1057.

van der Heyde, H. C., Nolan, J., Combes, V., Gramaglia, I., and Grau, G. E. (2006). A unified hypothesis for the genesis of cerebral malaria: sequestration, inflammation and hemostasis leading to microcirculatory dysfunction. Trends Parasitol. 22, 503-508. doi: 10.1016/j.pt.2006.09.002

van Meurs, M., Kumpers, P., Ligtenberg, J. J., Meertens, J. H., Molema, G., and Zijlstra, J. G. (2009). Bench-to-bedside review: angiopoietin signalling in critical illness - a future target? Crit Care 13, 207. doi: 10.1186/cc7153

Volz, J. C. (2013). Looking through a cranial window: intravital microscopy for in vivo study of cerebral malaria. Virulence 4, 661-663. doi: 10.4161/viru. 26802

Waknine-Grinberg, J. H., Hunt, N., Bentura-Marciano, A., McQuillan, J. A., Chan, H.-W., Chan, W.-C., et al. (2010). Artemisone effective against murine cerebral malaria. Malar. J. 9:227. doi: 10.1186/1475-2875-9-227

Wassmer, S. C., Moxon, C. A., Taylor, T., Grau, G. E., Molyneux, M. E., and Craig, A. G. (2011). Vascular endothelial cells cultured from patients with cerebral or uncomplicated malaria exhibit differential reactivity to TNF. Cell. Microbiol. 13, 198-209. doi: 10.1111/j.1462-5822.2010.01528.x

Wassmer, S. C., Taylor, T. E., Rathod, P. K., Mishra, S. K., Mohanty, S., ArevaloHerrera, M., et al. (2015). Investigating the pathogenesis of severe malaria: a multidisciplinary and cross-geographical approach. Am. J. Trop. Med. Hyg. 93, 42-56. doi: 10.4269/ajtmh.14-0841

W.H.O. (2011). World Malaria Report 2010. Geneva.

W.H.O. (2014). World Malaria Report 2013. Geneva.

Wilson, N. O., Jain, V., Roberts, C. E., Lucchi, N., Joel, P. K., Singh, M. P., et al. (2011). CXCL4 and CXCL10 predict risk of fatal cerebral malaria. Dis. Markers 30, 39-49. doi: 10.1155/2011/828256

Zanini, G. M., Cabrales, P., Barkho, W., Frangos, J. A., and Carvalho, L. (2011). Exogenous nitric oxide decreases brain vascular inflammation, leakage and venular resistance during Plasmodium berghei ANKA infection in mice. J. Neuroinflammation 8:66. doi: 10.1186/1742-2094-8-66

Zhao, Y., Maccormick, I. J., Parry, D. G., Beare, N. A., Harding, S. P., and Zheng, Y. (2015). Automated detection of vessel abnormalities on fluorescein angiogram in malarial retinopathy. Sci. Rep. 5:11154. doi: 10.1038/srep10425

Conflict of Interest Statement: The authors declare that the research was conducted in the absence of any commercial or financial relationships that could be construed as a potential conflict of interest.

Copyright (C) 2015 Sahu, Satpathi, Behera, Mishra, Mohanty and Wassmer. This is an open-access article distributed under the terms of the Creative Commons Attribution License (CC BY). The use, distribution or reproduction in other forums is permitted, provided the original author(s) or licensor are credited and that the original publication in this journal is cited, in accordance with accepted academic practice. No use, distribution or reproduction is permitted which does not comply with these terms. 